\title{
Improving the Quantity and Quality of Biogas Production in Tehran Anaerobic Digestion Power Plant by Application of Materials Recirculation Technique
}

\author{
Reza Naghavia , Mohammad Ali Abdolia, Abdolreza Karbasia ${ }^{a}$, Mehrdad Adlb ${ }^{*}$
}

${ }^{a}$ Faculty of Environment, University of Tehran, Iran

${ }^{b}$ Department of Energy, Materials and Energy Research Center, Karaj, Iran

\begin{abstract}
Tehran anaerobic digestion power plant has been built on the eastern margin of the urban district by the purpose of processing the organic fraction of municipal solid waste. One of the most suitable methods for the treatment of organic matter is the use of anaerobic digestion (AD) process, which in addition to significant reduction of organic solid wastes, will produce valuable energy. Contributing to maintain the environment, improve urban health, saving on fossil fuels and producing rich fertilizer for agricultural use are important advantages of anaerobic digestion. The plant has been set up in 2014 with a nominal acceptance capacity of 300 tons of organic solid wastes per day and the nominal power generation of $2000 \mathrm{kWe}$. This system has been faced with considerable challenges in terms of quantity and quality of biogas during operation. The high concentration of hydrogen sulfide $\left(\mathrm{H}_{2} \mathrm{~S}\right)$ in produced biogas and the lack of appropriate technologies in the plant for biogas refining are critical for the biogas generator engine deployed in the complex. The purpose of this article is to investigate the factors affecting the quality and quantity of Tehran's AD plant biogas using various $\mathrm{H}_{2} \mathrm{~S}$ reduction approaches and selection of appropriate implementing technologies. The results showed that the recirculation of the digester slurry increased the methane content by more than $30 \%$ and reduced $\mathrm{H}_{2} \mathrm{~S}$ by more than $98 \%$.C2020. CBIORE-IJRED. All rights reserved
\end{abstract}

Keywords: Organic waste, anaerobic digestion, biogas, hydrogen sulfide, material recirculation, waste management

Article History: Received: 26 ${ }^{\text {th }}$ March 2020; Revised: 19 ${ }^{\text {th }}$ April 2020; Accepted: $30^{\text {th }}$ April 2020; Available online: $2^{\text {nd }}$ May 2020

How to Cite This Article: Naghavi, R., Abdoli, M.A., Karbasi, A. and Adl, M. (2020) Improving the quantity and quality of biogas production in Tehran anaerobic digestion power plant by application of materials recirculation technique. International Journal of Renewable Energy Development, 9(2), 167-175.

https://doi.org/10.14710/ijred.9.2.167-175

\section{Introduction}

Solid waste management is a serious environmental and sanitation issue in developing countries specifically among urban areas. Rapid growth of urban populations and continuous increase in waste production deepens the challenge. The municipal solid wastes (MSW) often contain more than 50 percent of organic and biodegradable waste therefore, proper solutions by organic treatment basis can contribute to mitigate the problem of wastes (Khalid et al. 2011; Vögeli 2014).

Anaerobic digestion (AD) of biodegradable wastes leads to biogas production, this approach helps to improve waste management practices while also contributing the goals of sustainable energy management (Lissens et al., 2001; Hospido et al., 2005). The use of municipal biodegradable waste for biogas production creates a carbon neutral cycle in which carbon released from the combusted biogas is absorbed by new products where the residual digestate can be reused as raw material for biofertilizer (Tsachidou et al., 2019; Vögeli 2014).
Anaerobic digestion as one of the best technologies to produce highly valuable fertilizer and biogas as a carrier of renewable energy is recognized throughout the world. After a series of refining and upgrading processes, the biogas can be used as renewable alternative to natural gas (Wellinger 2013).

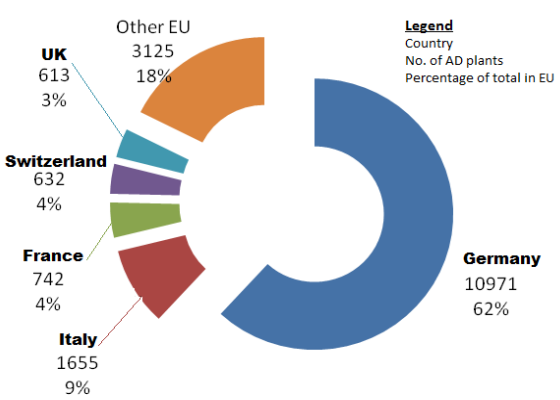

Fig. 1 Distribution of installed biogas plants among European Union and the share of top five countries by the end of 2017 (derived from EBA 2018)

\footnotetext{
* Corresponding author: adl.mehrdad@gmail.com
} 
In Europe, the market for the use of various materials for biogas production is rapidly expanding with a double digit growth rate every year, and it is expected to continue to grow in the next coming years. By the end of 2017 the number of biogas plants and cumulative installed capacity were reached 17738 and 10532MW among the European Union respectively from which Germany stood at the 1st rank with 10971 plants (EBA 2018). Figure 1 demonstrates the share of top 5 European countries in total number of biogas plants. Various types of the raw materials are needed for biogas production plants in Europe among which, energy crops and agricultural residues are predominant input however, organic fraction of municipal solid wastes (OFMSW) provides a significant share in some countries such as Finland, Austria and Portugal (EBA 2018).

Anaerobic digestion of biodegradable wastes provides several benefits by converting organic wastes into valuable products. This includes producing renewable energy, reducing greenhouse gas emissions, reducing fossil fuel dependency, creating job opportunities, compensating waste disposal costs and completing the food cycle (Wellinger 2013). Biogas as a renewable energy source not only improves a country's energy balance, but also helps preserve natural resources by reducing deforestation and protecting the environment by reducing waste pollution and using fossil fuels (Vögeli 2014).

Biogas as a renewable energy source has wide variable applications from cooking and heating to electricity generation as well as upgrading to biomethane in order to conversion into bio-CNG or injection to natural gas grid (Wellinger 2013).

The AD technology and its influential elements has been demonstrated by the scientists in three main components including: substrate chain, conversion process, and product chain. Waste production, collection, transportation and supply to digestion facilities comprise the substrate chain before the waste treatment and before feeding to digesters. Conversion process includes all the biological and chemical conversion processes of raw material in $\mathrm{AD}$ that incorporate into valuable products. The product chain is formed by a series of modifying and improvement practices that provide the refined products from digestion section into the commercial distribution section (Vögeli 2014). A graphical description of the aforementioned chains is demonstrated in Figure 2.

The waste-to-energy technologies were initially developed in Iran during early 2000s by installation of landfill gas-to-energy projects following by $\mathrm{AD}$ plants for utilization of various organic waste resources (Adl \& Omrani 2008). The Municipality of Tehran started the country's first implementation of $\mathrm{AD}$ technology for organic fraction of MSW in 2011 that was commissioned and started its operating in 2014. The project was a pioneer environmental act for the purpose of reducing the waste landfilling acceptance rate in Aradkuh complex as well as the MSW transportation rate across Tehran megapolis and simultaneously facilitate energy generation from biodegradable solid wastes.

Tehran AD plant is located on the eastern boundary of the capital's urban area. The plant has a nominal 300t/d MSW acceptance capacity and comprises main sections including waste sorting and classification from which OFMSW is separated and sent to the next section that is $\mathrm{AD}$ process facility from which biogas is produced and transmitted to the utilization section where biogas treatment and conversion into heat and power take place. Two biogas-fueled Cummins engine generating sets have been installed in biogas utilization section to supply a nominal $2000 \mathrm{kWe}$ power along with process heat in the form of co-generation.



Fig. 2 Anaerobic Digestion Process Chain

Measurement, control and adjustment of parameters' interrelation play crucial roles on the digester's efficiency as well as on quality and quantity of produced biogas. As described in the next section, this $\mathrm{AD}$ plant worked far below its anticipated energy productivity. One significant challenge during the plant's practical operation was the high content of hydrogen sulfide in the produced biogas. During this research trials made in order to reduce the formation of hydrogen sulfide in biogas and increase the efficiency of the Tehran AD plant by the mean of several techniques among which, supplying suitable substrates' composition and employing appropriate materials recirculation were examined as an economical effective solution to be evaluated as the main objective of this fullscale research.

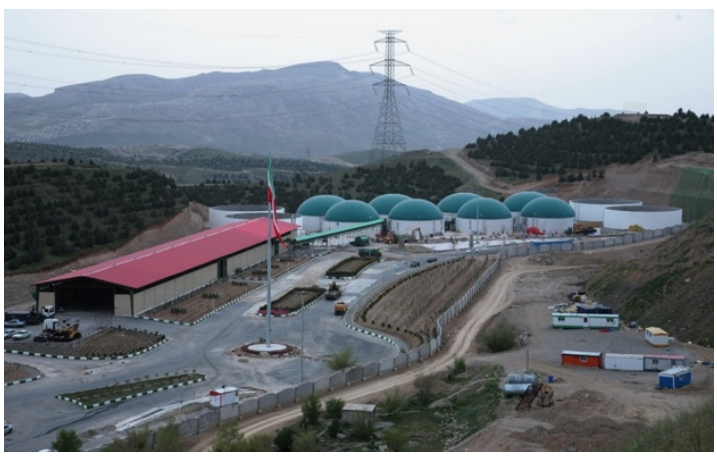

Fig. 3 Overview of Tehran AD power plant

\section{Materials and Methods}

\subsection{Short description of Tehran MSW management and AD power plant}

According to the latest statistics from Tehran Municipal Waste Management Organization, a population of about 9 million people, with an area of 896 square kilometres, 
produces some 6200 tones of MSW daily. This amount of solid wastes are collected by 1346 vehicles and transported to 11 intermediate stations. The residues are transported to Aradkuh Processing and Disposal Complex after being discharged into a fleet of 126 Semi Trailers. Analyzes of the household solid wastes in Tehran showed that about $70 \%$ of which is organic and can be converted into an energy carrier (biogas) and compostable digestate through $\mathrm{AD}$ process. MSW streams from two urban districts of Tehran were dedicated to the $\mathrm{AD}$ plant upon commissioning schedule in order to supply 300t/d. Former MSW classification practices by Tehran's Municipality had been resulted in waste composition identifications during 2008 and 2017 from which, data regarding to urban districts \#1 and \#4 has been summarized in Table 1 .

However in practice, on average, about $120 \mathrm{t} / \mathrm{d}$ of MSW is received out of $300 \mathrm{t} / \mathrm{d}$ capacity from one intermediate transfer station. As shown in Figure 4, the accepted fresh MSW is initially processed on waste sorting platforms (with 30 workers) on which, bag opener and rotary-drumscreen along with rolling belts play the key role in waste classification. The fine fraction that is collected from subscreen is shredded in a refiner and mixed with the recycled digestion effluent from the secondary digestion tank, the final digester's effluent and fresh water in pre-defined ratios within the pre-digester tank where the contents possess a complete homogenization. Substances in the said tank, according to a specified operating schedule, are transported to the primary digester tanks with a fixed volume and, after the required time elapsed, are transferred to the secondary digester tanks (approximately 28 days in total) and from there to the final tanks.

Table1

MSW composition of urban districts supplying input to the AD plant (all values in \% wet weight basis)

\begin{tabular}{|c|c|c|c|c|}
\hline \multirow{3}{*}{ Constituent } & \multicolumn{4}{|c|}{ Year } \\
\hline & \multicolumn{2}{|c|}{2008} & \multicolumn{2}{|c|}{2017} \\
\hline & District 1 & District 4 & $\begin{array}{c}\text { District } \\
1\end{array}$ & $\begin{array}{c}\text { District } \\
4\end{array}$ \\
\hline Metals & 2.6 & 1.9 & 1 & 0.4 \\
\hline Glass & 2.5 & 1.8 & 0.9 & 1.3 \\
\hline $\begin{array}{l}\text { Paper \& } \\
\text { cardboard }\end{array}$ & 15.2 & 9.4 & 4.2 & 4.2 \\
\hline $\begin{array}{l}\text { Plastics \& } \\
\text { foam }\end{array}$ & 8.4 & 8.1 & 11.7 & 13.7 \\
\hline Rubber & negligible & 0.6 & negligible & 0.2 \\
\hline $\begin{array}{l}\text { Leather \& } \\
\text { textiles }\end{array}$ & 0.7 & 1.2 & 2.8 & 2.7 \\
\hline Organics & 68.7 & 73.6 & 78.3 & 73 \\
\hline Wood & 0.1 & 0.6 & 0.2 & 1.6 \\
\hline Others & 1.8 & 2.8 & 0.9 & 2.9 \\
\hline
\end{tabular}

Source: Municipality of Tehran, Waste Management Org. (2018)

The structure of the Tehran AD power plant is reinforced concrete and was established on a land of approximately 3 hectares. There are 14 tanks with the following capacities:

- 2 pre-chambers each by 500 cubic meters capacity

- 4 primary digestion tanks each by 1200 cubic meters capacity
- 4 secondary digestion tanks each by 1500 cubic meters capacity

- 4 final tanks each by 2500 cubic meters capacity

The $\mathrm{AD}$ process in this plant is based on the two-stage wet mesophilic type through which, feeding the tanks is followed by a continuous regime and digesters are operated under completely mixed procedure.

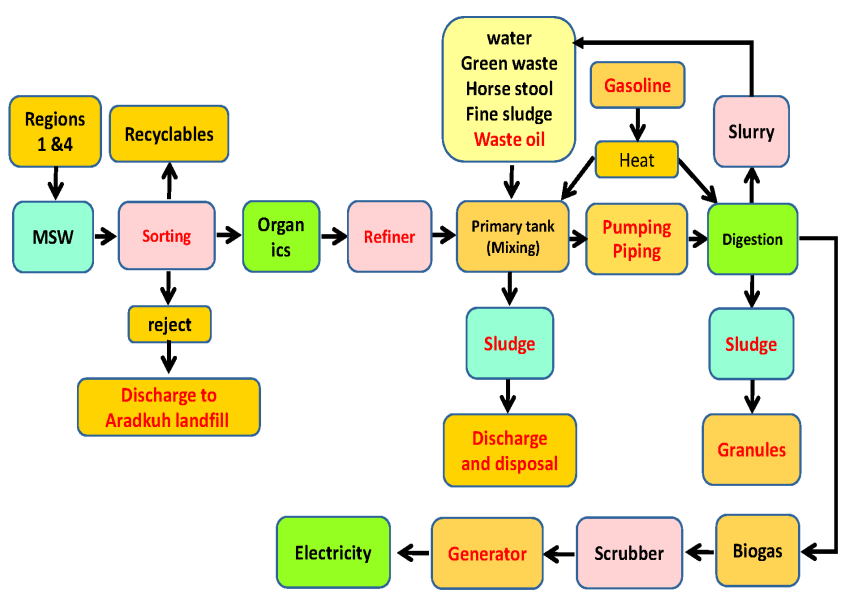

Fig. 4 The process flow-diagram of Tehran $\mathrm{AD}$ power plant

\subsection{Challenge definition}

The plant continued its operational activity from 2015 to late 2016 by accepting MSW from capital's urban regions \#1 and \#4 but for reasons it could generate only a cumulative $496 \mathrm{MWh}$ of electricity which was a very small figure compared to the anticipated generation due to the 2MWe nominal capacity of the complex and gross working hours over the period.

The main obstacle in converting the municipal waste into methane is its heterogeneous nature and complex structure. The success in the laboratory scale $\mathrm{AD}$ pilot and identification of the factors contributing to the economic and environmental feasibility are the primary requirements for the success of the full-scale project, which has not been addressed in Tehran AD plant. Given that this project was the very first MSW-fed plant implemented in the country, there were many unknown problems, some of which are as follows.

Inappropriate Technology: The technology and some of the existing power plant equipment were not tailor made for anaerobic digestion in Tehran and were designed solely on the basis of uniform and homogenous feed such as agricultural waste or high purity organic materials.

Mismatch between the sorting technology with Tehran MSW composition: based on the initial design of the sorting line, it should fulfil the acceptance capacity of 300 tonnes of municipal mixed waste daily with more than $90 \%$ purity in OFMSW output. At present, the line is capable of accepting up to 120 tonnes per working shift and has a purity efficiency of $74 \%$ at the output.

Excessive sludge production from impurities: Impurities in the input materials cause excessive sludge production in the tanks and reduce their effective volume, thereby reducing gas production and collection efficiency. 
Citation: Naghavi, R., Abdoli, M.A., Karbasi, A. and Adl, M. (2020) Improving the quantity and quality of biogas production in Tehran anaerobic digestion power plant by application of materials recirculation technique. Int. Journal of Renewable Energy Development, 9(2), 167-175, doi: 10.14710/ijred.9.2.167-175

P a g e 170

Formation of high hydrogen sulfide in biogas: following the provided instructions by the plant commissioner did not comply with the municipal waste type of Tehran and resulted in the production of biogas with a very high $\mathrm{H}_{2} \mathrm{~S}$ content (around 15,000 ppm or even over). The existing biogas-scrubber despite the high operational costs and use of different chemicals could not ultimately lower the H2S content below 3,000 ppm. High levels of $\mathrm{H}_{2} \mathrm{~S}$ corroded some parts of the biogas-fueled generating sets.

\subsection{Characterization of input materials}

The entered solid wastes to the plant are divided into three categories after sorting line, including recyclables (3 to $5 \%$ ), biodegradables (37 to $48 \%$ ), and non-recyclable wastes (49 to $58 \%$ ).

The biodegradable fraction of solid waste stream in Tehran $\mathrm{AD}$ plant was subjected to the proximate and ultimate analysis which results have been summarized in Table 2 .

\section{Table 2}

Proximate and ultimate analysis results for biodegradable fraction of solid wastes in the AD plant

\begin{tabular}{|lcc|}
\hline \multirow{2}{*}{ Parameter } & \multicolumn{2}{c}{ Measured results } \\
\cline { 2 - 3 } & $\begin{array}{l}\text { Paper, } \\
\text { newspaper } \\
\text { and cardboard }\end{array}$ & $\begin{array}{c}\text { Food waste (fruit, } \\
\text { vegetable \& } \\
\text { kitchen residues) }\end{array}$ \\
\hline Dry matter (\%) & 90.2 & 30.6 \\
Moisture content (\%) & 9.8 & 69.4 \\
Carbon (\% of DM) & 45.8 & 48.1 \\
Hydrogen (\% of DM) & 6.3 & 6.0 \\
Oxygen (\% of DM) & 39.5 & 37.8 \\
Nitrogen (\% of DM) & 2.8 & 2.6 \\
Sulphur (\% of DM) & 0.43 & 0.43 \\
Ash (\% of DM) & 5.2 & 5.1 \\
\hline
\end{tabular}

Source: Municipality of Tehran (2018)

As a consequence the hypothetical chemical composition of the OFMSW at Tehran AD plant entrance was obtained according to the Table 2 as follows:

$$
\begin{aligned}
& C_{102.7} H_{166.7} O_{65.7} N_{4.7} S \text { (excluding water content) } \\
& C_{102.7} H_{280} O_{121.3} N_{4.7} S \text { (including water content) }
\end{aligned}
$$

\subsection{Measurement of process parameters}

The most influential parameters regarding the $\mathrm{AD}$ process were selected and measured according to the scientific procedures as recommended by Lin et al. (2001) during the certain monitoring periods. The parameters concerning the digester contents included: $\mathrm{pH}$, electrical conductivity (EC), total solids (TS), volatile solids (VS), total alkalinity(TAK), total volatile fatty acids (VFA), and chemical oxygen demand (COD). The biogas related parameters included methane $\left(\mathrm{CH}_{4}\right)$, carbon dioxide $\left(\mathrm{CO}_{2}\right)$ and hydrogen sulfide $\left(\mathrm{H}_{2} \mathrm{~S}\right)$ content. Slurry samples were taken from both inlet and outlet of the digesters after which, total COD was measured following the method recommended by APHA Standard Methods (1998).

Biogas composition parameters were measured by a portable gas analyzer marked GeoTech ${ }^{\circledR}$ GA-5000 at defined periods from the sampling ports on the biogas pipelines.

\subsection{Modification and improvement practices}

As the AD plant demonstrated its low productivity due to the aforementioned problems, corrective activities were adopted and performed in two categories: modification of the feed composition, and reduction/removal of $\mathrm{H} 2 \mathrm{~S}$ content in biogas.

\subsubsection{Feed composition modification}

Entrance of chemical and industrial wastes into the MSW stream from urban district \#4 that was frequently occurring due to the existence of workshops and factories on the periphery of that region imposed biological shock to the digester reactors therefore, MSW acceptance from district \#4 was stopped and district \#1 was substituted instead as it was the 2 nd closest district to the location of AD plant.

Furthermore, in order to improve the substrate quality and reduce the volume of inorganic daily sludge, 8 tonnes of green waste from the Central Fruit and Vegetable Market (with more than 95\% organic purity) and 4 tonnes of horse manure were mixed with the daily OFMSW charge in the pre-chamber tank and the homogenized mixture were pumped into the primary digester tanks according to the specified operating schedule. The flow from primary digesters was being transferred to the secondary digesters and finally to the post-digesters following the predefined loading rates and retention times.

\subsubsection{Implementation of various methods to reduce or remove hydrogen sulfide in biogas}

Toxicity and corrosion potential of hydrogen sulfide in the raw biogas mandated biogas treatment to lower the $\mathrm{H} 2 \mathrm{~S}$ content below the allowed level as recommended by the engine gen-set manufacturer. During this research nine various methods were considered consecutively in order to desulfurize the biogas flow in the $\mathrm{AD}$ plant as follows.

1. $\mathrm{H}_{2} \mathrm{~S}$ removal by alkaline solution scrubbing

2. $\mathrm{H}_{2} \mathrm{~S}$ removal by addition of iron chloride to the digester contents

3. $\mathrm{H}_{2} \mathrm{~S}$ removal by adsorption on iron oxide packed bed reactor

4. $\mathrm{H}_{2} \mathrm{~S}$ removal by adsorption on activated carbon packed bed reactor

5. $\mathrm{H}_{2} \mathrm{~S}$ removal by adsorption on zeolite packed bed reactor

6. $\mathrm{H}_{2} \mathrm{~S}$ removal via bio-scrubber reactor using aerobic sulfur-oxidizing bacteria

7. $\mathrm{H}_{2} \mathrm{~S}$ removal by partial air injection into biogas digester

8. $\mathrm{H}_{2} \mathrm{~S}$ removal by recirculation of digested materials

9. $\mathrm{H}_{2} \mathrm{~S}$ removal by combination of material recirculation and air injection

A comprehensive description about methods 1 through 7 is available in the report prepared by Bauer et al. (2013) while methods 8 and 9 were designed and examined by the research team.

The framework of method 8 comprised of partial recirculation of digested slurry from secondary digesters to the pre-chambers in which it was added to the mixture of sorted OFMSW, green fruit and vegetable $(\mathrm{F} \& \mathrm{~V})$ wastes, horse manure and fresh water where the final 
homogenized mixture was being conveyed to the primary digesters as illustrated in Figure 5.

During the examination of method 9 the same recirculation scenario was performed along with the air injection to the biogas storage space of the digesters. The amount of air flow rate was adjusted on the basis of biogas flow rate and its $\mathrm{H}_{2} \mathrm{~S}$ content according to the procedures reviewed by Krayzelnova et al. (2015).

\section{Results and discussion}

The aforementioned improving methods demonstrated different performances upon examining in Tehran $\mathrm{AD}$ plant through which the summary of highlighted results are presented in Table 3. It should be mentioned that the total COD of the input mixture at the inlet of primary digester varied between 38000 to $42000 \mathrm{mg} / \mathrm{l}$ meanwhile the average $\mathrm{H}_{2} \mathrm{~S}$ content of raw biogas at the gas header pipe of the digesters was in the range of 15000 to 20000ppm.

The method 1 was performed by the use of sodium hydroxide solution in a packed bed scrubber and could decrease the $\mathrm{H}_{2} \mathrm{~S}$ to around $3000 \mathrm{ppm}$ in biogas stream. It was not capable to refine the biogas down to the desired level of $200 \mathrm{ppm}$ which was the allowable threshold required by the gen-set manufacturer due to the massive biogas flow-rate in this plant. Another disadvantage of this method was the problem of exhaust alkaline solution disposal along with the significant operational cost of chemical supply therefore, the alkaline scrubbing method was identified inappropriate for the current $\mathrm{AD}$ plant.

The method 2 that was initially introduced by Dezham et al.(1988) is more suitable for small anaerobic digesters and performs effective in reducing $\mathrm{H}_{2} \mathrm{~S}$ values to achieve an output concentration of less than 100ppm and in enhancement of $\mathrm{CH} 4$ content and odor reduction as well but it seems inappropriate and non-economical for large digester plants since for each $\mathrm{kg}$ of $\mathrm{H}_{2} \mathrm{~S}$ up to $5.4 \mathrm{~kg}$ of ironchloride solution $\left(\mathrm{FeCl}_{3}, 40 \%\right.$ purity) might be consumed (Park \& Novak, 2013). This method showed unsuccessful in this project as it could not lower $\mathrm{H}_{2} \mathrm{~S}$ below 5000ppm so even though this method showed a good result in $\mathrm{CH}_{4}$ content it was rejected from the list of feasible methods for biogas improvement at this large-scale plant. The raise in methane content could be attributed to the influential effect of iron ions on AD process (Park,2013; Wellinger et al., 2013)

The $3^{\text {rd }}$ method is suitable for the treatment of low volumes of biogas with low $\mathrm{H}_{2} \mathrm{~S}$ content as well (Janetaisong et al., 2017). An iron-oxide packed bed reactor was employed as a downstream unit operation for qualitative biogas improvement and showed almost the same performance as the method 2 hence, it was concluded to ignore it for this $\mathrm{AD}$ plant.

The method 4 was tested in a pilot-scale adsorption bed reactor by employing a partial flow rate from the real biogas stream in the plant. The adsorption bed was packed by activated carbon impregnated with potassium iodide and operated under pressurized condition (5 to 7 bar) according to Zulkefli and co-workers (2019) while it could decrease H2S content only less than $50 \%$ and appraisals by the research team were concluded against selection of this method due to the technical restrictions for full-scale and high operational costs.
Although zeolite bed reactor had been successfully examined by Cosoli and coworkers (2008) at a pilot-scale study for desulfurization of biogas nevertheless for the high-sulfur high-flow rate biogas stream in Tehran AD plant this method could not lower the H2S content below $8800 \mathrm{ppm}$ therefore, the method 5 was also rejected for fullscale operation.

The $\mathrm{H}_{2} \mathrm{~S}$ removal process by bio-scrubber as employed via method 6 is a proven commercialized technique (Syed et al., 2006; Bauer et al., 2013) that showed its perfect capability in small family sized biogas units by outputting H2S concentration as low as 9 ppm (Haryanto et al., 2017). Although a bio-scrubber tower had already been commissioned by the plant suppliers but it was not capable to reduce the $\mathrm{H}_{2} \mathrm{~S}$ content below 3000ppm in the practical conditions during the several months of plant operation. This situation was the main driving force for the current research work.

The injection of air into the biogas stream (method 7) showed a better performance than the former six methods in terms of H2S removal nevertheless the level of $\mathrm{H}_{2} \mathrm{~S}$ in the treated biogas was still significantly higher than the acceptable threshold. On the other hand the implementation of this method requires the use of online gas analyzers to avoid the risk of fire and explosion (Krayzelova et al., 2015).

Recirculation of digested material has a positive effect on methane yield and organic loading rate since it significantly increases the alkalinity and buffer capacity of the system, maintaining optimum $\mathrm{pH}$ for methanogens. Therefore proper control of the two-stage system of anaerobic digesters coupled with recirculation of digested material increases the amount of methanogenic bacteria in the digestive process by which, not only regulates the loading of organic matter but also prevents ammonia accumulation and ultimately reduces the amount of hydrogen sulfide in the biogas composition while increases the rate of biogas production (Moestedt et al., 2016).

Recirculation of digested sludge on the other hand should carefully be adjusted in order to prevent the accumulation of ammonia in the digester contents which is toxic for methanogenic bacteria upon excess concentration and consequently will interrupt the methane generation (Masse et al., 2014; Silvestre et al., 2015). In critical organic loading rate (OLR) conditions, ammonium accumulates on the equilibrium threshold between the hydrolyzing bacteria and the methanogens. According to the observations in the recent studies, a strategy for controlling $\mathrm{pH}$ is crucial in the first stage of the $\mathrm{AD}$ system by linking the acidification step with the methanogenesis step through employing the recirculation of buffer containing digested material to increase the $\mathrm{pH}$ of the acidification reactor (Micolucci et al., 2014).

The accumulation of fatty acids eventually results in a decrease in $\mathrm{pH}$ and the methanogenic reactions drop meanwhile increase in formation sulfide ions takes place which in turn leads to release of excessive amounts of H2S molecules in biogas. Therefore, proper control of two-stage $\mathrm{AD}$ systems by partial recirculation of digested material is not only influential to the regulation of OLR but also to the prevention of ammonia accumulation (Wu et al., 2018).

The digestate recirculation technique (method 8) worked well in the $\mathrm{AD}$ plant during this study despite the high biogas flow rate and rich $\mathrm{H}_{2} \mathrm{~S}$ content as evident the average concentration of $\mathrm{H}_{2} \mathrm{~S}$ was observed as low as 
$55 \mathrm{ppm}$ in biogas stream. Figure 5 shows the paths and ratios of feeding and materials recirculation in $\mathrm{AD}$ process within the full-scale operation of Tehran plant.

During the $9^{\text {th }}$ method air was slightly injected to the biogas storage space beside the recirculation of digested sludge from the secondary digesters and it was observed that the hydrogen sulfide concentration was the lowest among the all 9 methods. Due to the risk of explosion in the digestive environment due to mixing of oxygen and methane, injection of air or oxygen must be carefully adjusted and based on continuous biogas quality analysis results, installation of an online analyzer on the biogas line will be necessary.

A comparison between the aforementioned nine methods in terms of biogas and methane productivity has graphically been illustrated in Figure 6. Considering Table 3 and Figure 6 it is evident that the method 9 showed the best performance in $\mathrm{H}_{2} \mathrm{~S}$ removal nevertheless, taking the practical conditions into account, this method was not economically viable. The materials recirculation technique (method 8) was the most cost effective H2S reduction method in this full-scale process.
Subsequently extended operation of the $\mathrm{AD}$ plant was planned under the fundamentals of this technique in the form of an experimental operating arrangement as shown in Figure 5 through which the viability of this technique was proved in terms of continuous production of rich methane biogas with low sulphur content.

A multi-aspect appraisal of the 9 process modification methods in this study has been summarized in Table 4. Three categories of parameters including environmental, economical and executive have been considered for comparative assessment of the methods. Since methods 8 and 9 demonstrated almost similar methane productivity therefore method 8 was preferred due to the economical considerations.

The quantity of methane productivity outcome of methods 8 or 9 (ca. $49 \mathrm{Nm}^{3}$ per ton of fresh substrate) however was comparable to a similar figure in a full-scale $\mathrm{AD}$ plant in Villeneuve, Switzerland that was measured by Holliger et al (2017) equal to $47.1 \pm 5.5 \mathrm{Nm}^{3} / \mathrm{t}_{\mathrm{fW}}$ when utilizing green wastes and $88.2 \pm 15.9 \mathrm{Nm}^{3} / \mathrm{t}_{\mathrm{fW}}$ upon utilizing food wastes respectively.

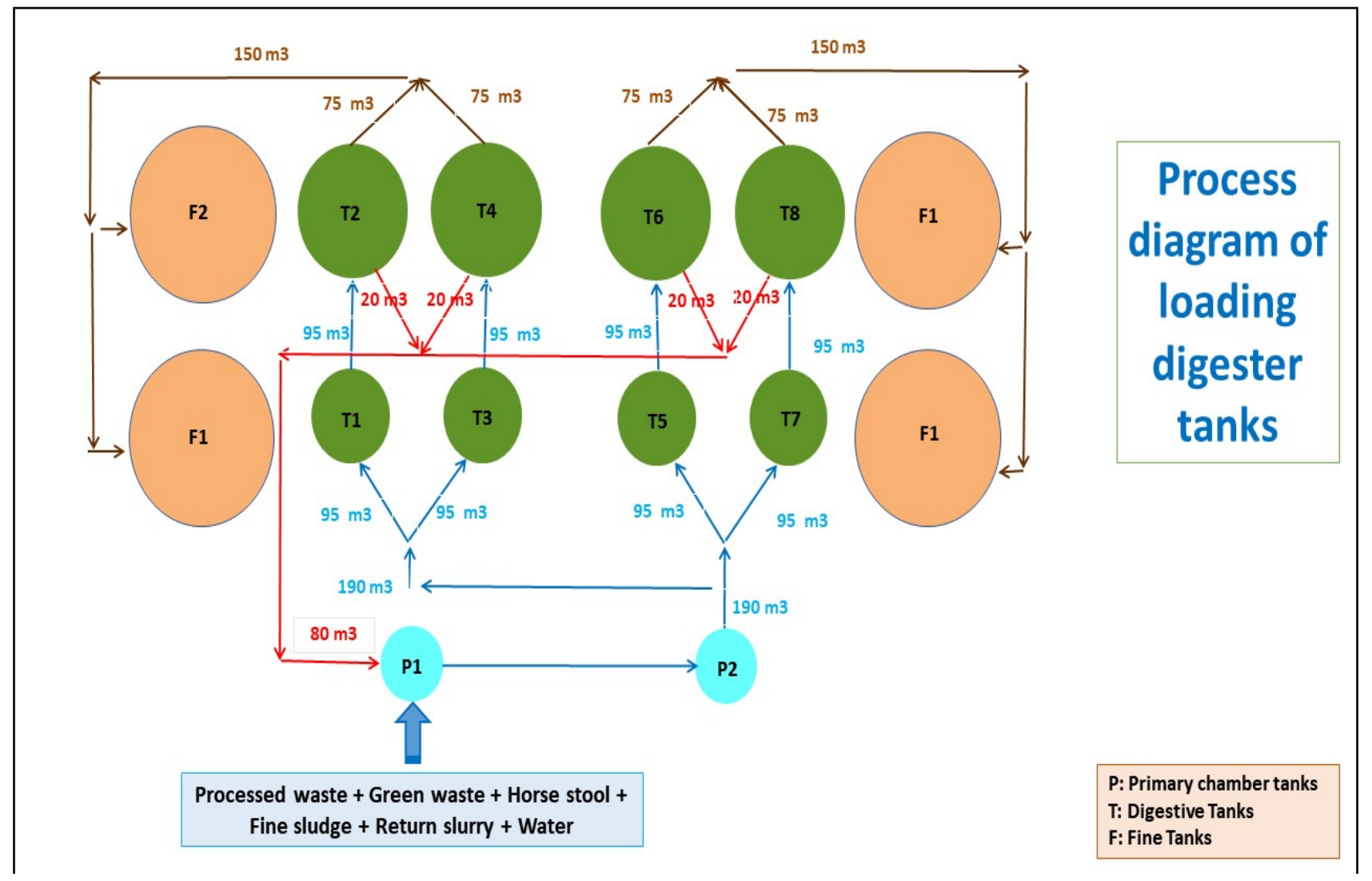

Fig. 5 Schematic illustration of materials recirculation and mixing ratios adjustment regarding the Method 8 in Tehran AD plant 
Table 3

The quantity of the selected process parameters after implementation of modifying methods

\begin{tabular}{|c|c|c|c|c|c|c|c|c|c|c|}
\hline Monitoring item & $\mathrm{pH}$ & $\begin{array}{c}\text { EC } \\
(\mathrm{ds} / \mathrm{m})\end{array}$ & $\begin{array}{c}\text { TS at } \\
\text { outlet(\%) }\end{array}$ & $\begin{array}{c}\text { VS at } \\
\text { outlet(\%) }\end{array}$ & $\begin{array}{l}\text { VFA } \\
(\mathrm{mg} / \mathrm{l})\end{array}$ & $\begin{array}{l}\text { TAK } \\
(\mathrm{mg} / \mathrm{l})\end{array}$ & $\begin{array}{l}\mathrm{CH}_{4} \\
(\%)\end{array}$ & $\begin{array}{l}\mathrm{CO}_{2} \\
(\%)\end{array}$ & $\begin{array}{c}\mathrm{H}_{2} \mathrm{~S} \\
(\mathrm{ppm})\end{array}$ & $\begin{array}{l}\text { COD at outlet } \\
(\mathrm{mg} / \mathrm{l})\end{array}$ \\
\hline $\begin{array}{l}\text { Measurement } \\
\text { interval }\end{array}$ & Daily & Daily & Daily & Daily & $\begin{array}{l}3 \text { days } \\
\text { once }\end{array}$ & $\begin{array}{l}3 \text { days } \\
\text { once }\end{array}$ & Daily & Daily & Daily & End of period \\
\hline Method 1 & 7.0 & 14 & 3.0 & 60 & 6,630 & 6,580 & 54 & 40 & 3,200 & 20,000 \\
\hline Method 2 & 8.0 & 17 & 5.0 & 50 & 1,210 & 13,200 & 60 & 34 & 5,200 & 27,000 \\
\hline Method 3 & 7.5 & 15 & 4.0 & 61 & 1,280 & 14,100 & 56 & 41 & 5,500 & 26,000 \\
\hline Method 4 & 7.0 & 14 & 4.5 & 51 & 1,100 & 8,100 & 62 & 37 & 9,600 & 29,000 \\
\hline Method 5 & 6.8 & 16 & 5.0 & 53 & 1,480 & 7,200 & 58 & 38 & 8,800 & 26,000 \\
\hline Method 6 & 7.2 & 13.5 & 5.4 & 58 & 2,300 & 11,400 & 55 & 33 & 9,100 & 25,000 \\
\hline Method 7 & 7.3 & 16 & 6.0 & 46 & 4,800 & 15,000 & 63 & 30 & 1,300 & 18,000 \\
\hline Method 8 & 7.0 & 18 & 6.2 & 42 & 5,900 & 16,000 & 65 & 25 & 55 & 16,500 \\
\hline Method 9 & 6.9 & 15 & 5.8 & 54 & 4,200 & 15,800 & 64 & 30 & 10 & 15,000 \\
\hline
\end{tabular}

Table 4

Comparative assessment results for biogas improvement methods examined in Tehran AD plant

\begin{tabular}{|c|c|c|c|c|c|c|c|c|c|c|c|}
\hline \multirow[b]{3}{*}{ Description } & \multicolumn{9}{|c|}{ Assessment } & \multirow[b]{3}{*}{$\begin{array}{l}\mathrm{H}_{2} \mathrm{~S} \\
\text { removal } \\
\text { method }\end{array}$} & \multirow[b]{3}{*}{$\begin{array}{l}\text { Method } \\
\text { No. }\end{array}$} \\
\hline & \multicolumn{3}{|c|}{ Executive } & \multicolumn{3}{|c|}{ Economic } & \multicolumn{3}{|c|}{ environmental } & & \\
\hline & $\underset{2}{2}$ & $\frac{3}{2}$ & 정 & 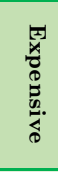 & 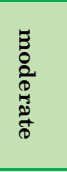 & 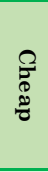 & 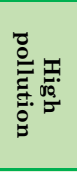 & 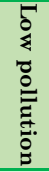 & 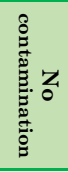 & & \\
\hline $\begin{array}{l}\text { Due to the high volume of biogas produced } \\
\text { and the high percentage of } \mathrm{H}_{2} \mathrm{~S} \text { contained in it } \\
\text { and the high cost of producing sodium } \\
\text { hydroxide and toxic effluent production, it was } \\
\text { not feasible to continue this method. }\end{array}$ & * & & & * & & & * & & & $\begin{array}{l}\text { By alkaline } \\
\text { scrubbing with } \\
\text { sodium } \\
\text { hydroxide }\end{array}$ & 1 \\
\hline $\begin{array}{l}\text { This method works for the treatment of low } \\
\text { volumes of biogas with low H2S content. }\end{array}$ & & & * & * & & & & * & & $\begin{array}{l}\text { By addition of } \\
\text { ferric chloride }\end{array}$ & 2 \\
\hline $\begin{array}{l}\text { This method is suitable for the treatment of } \\
\text { low volumes of biogas with low } \mathrm{H}_{2} \mathrm{~S} \text { content. }\end{array}$ & * & & & & * & & & * & & $\begin{array}{l}\text { By adsorption } \\
\text { on iron oxide }\end{array}$ & 3 \\
\hline $\begin{array}{l}\text { This method is suitable for the treatment of } \\
\text { low volumes of biogas with low } \mathrm{H}_{2} \mathrm{~S} \text { content. }\end{array}$ & & * & & * & & & & * & & $\begin{array}{l}\text { By activated } \\
\text { carbon }\end{array}$ & 4 \\
\hline $\begin{array}{l}\text { This method is suitable for the treatment of } \\
\text { low volumes of biogas with low H2S content. }\end{array}$ & & * & & & * & & & * & & $\begin{array}{l}\text { By adsorption } \\
\text { on zeolite }\end{array}$ & 5 \\
\hline $\begin{array}{l}\text { This method is suitable for the treatment of } \\
\text { low volumes of biogas with low H2S content. }\end{array}$ & & * & & * & & & & & * & $\begin{array}{l}\text { Using sulfur- } \\
\text { oxidizing } \\
\text { bacteria }\end{array}$ & 6 \\
\hline $\begin{array}{l}\text { Due to the high biogas production flow rate } \\
\text { and the high content of } \mathrm{H} 2 \mathrm{~S} \text {, this method was } \\
\text { almost effective. }\end{array}$ & & & * & * & & & & & * & $\begin{array}{l}\text { By injecting } \\
\text { oxygen / air into } \\
\text { the digester } \\
\text { tanks }\end{array}$ & 7 \\
\hline $\begin{array}{l}\text { Due to the high biogas production flow rate } \\
\text { and the high content of } \mathrm{H} 2 \mathrm{~S} \text {, this method was } \\
\text { quite effective. }\end{array}$ & & & * & & & * & & & * & $\begin{array}{l}\text { By } \\
\text { recirculation } \\
\text { the material in } \\
\text { the process of } \\
\text { loading the } \\
\text { digester tanks }\end{array}$ & 8 \\
\hline $\begin{array}{l}\text { This method was fully effective but requires } \\
\text { online equipment and control and is at high } \\
\text { risk. }\end{array}$ & & * & & & * & & & & * & $\begin{array}{l}\text { Combination of } \\
\text { oxygen / air } \\
\text { injection } \\
\text { methods and } \\
\text { material } \\
\text { recirculation } \\
\end{array}$ & 9 \\
\hline
\end{tabular}




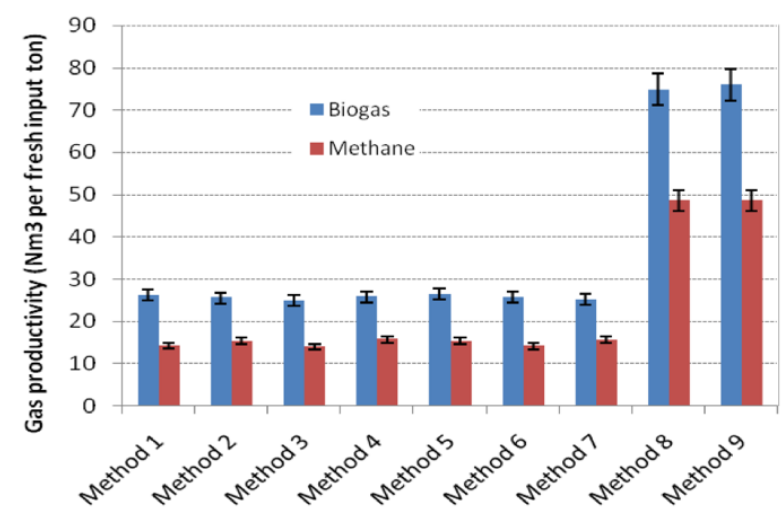

Fig. 6 Comparison of methane and biogas productivity during the examination of 9 various modification methods

\section{Conclusion}

This study demonstrated the capability of several techniques within a full-scale two-stage $\mathrm{AD}$ process towards increased production of good-quality biogas in terms of high methane content and very low hydrogen sulfide concentration. In two-step digestions with recirculation of digested material, the alkalinity of the system is greater than that of simple stream digesters (single-step or two-step) which is rich in buffering agents.

In this study the research team tried to find a way to produce suitable biogas with high methane and low H2S levels by examining different methods of hydrogen sulfide reduction. All experiments were performed on an industrial full-scale among which the materials recirculation technique was the most efficient and the least costly method. This technique with environmental benefits due to the reduction of chemical consumption oriented pollutions, could improve the technical efficiency and increased electrical energy productivity thus economic viability. After applying this technique to ensure the performance over a 100 day period, a generator engine could continuously generate electricity without significant problems.

Further investigations concerning the adjustment of input feed composition and mixing ratios between feed and recirculated material as well as the retention time in the digester tanks are recommended as the future studies.

\section{Acknowledgments}

The authors should warmly appreciate the contributions made by the Waste Management Organization of Municipality of Tehran as well as the invaluable helps by Mr. Kamran Legzian and Mr. A. Meydanaki during this research work.

\section{References}

Adl, M. and Omrani, G. (2008) Background of biogas technology and its recent developments in Iran. Int J Global Energy Issues, 29(1),273-283
APHA (American Public Health Association), (1998) Standard methods for the Experimental of Water and Wastewater, APHA Washington, D.C.

Bauer, F., Persson, T., Hulteberg, C., \& Tamm, D. (2013). Biogas upgrading- Technology overview, comparison and perspectives for the future. Biofuels, Bioproducts and Biorefining, 7(5), 499-511

Cosoli, P., et al. (2008) Hydrogen sulfide removal from biogas by zeolite adsorption, Part II: MD simulations. Chemical Engineering Journal. 145(1): 93-99.

Dezham, P., Rosenblum, E., Jenkins, D. (1988) Digester gas control using iron salts. Journal of Water Pollution Control Federation, 514-517

EBA (2018) Annual Statistical Report of the European Biogas Association: European Overview Chapter

Haryanto A., Marotin F., Triyono S., Hasanudin U. (2017) Developing a family size biogas-fueled electricity generating system. Int. Journal of Renewable Energy Development, 6(2): 111-118

Holliger C., Fruteau H., Hack G. (2017) Methane production of full-scale anaerobic digestion plants calculated from substrate's biomethane potentials compares well with the one measured on-site. Frontiers in Energy Research, 5:12. DOI: 10.3389/fenrg.2017.00012

Hospido, A., Moreira, T., Martin A., Rigola M., Feijoo G. (2005). Environmental evaluation of different treatment processes for sludge from urban wastewater treatments: Anaerobic digestion versus thermal processes. The International Journal of Life Cycle Assessment,. 10(5): 336-345.

Janetaisong, P., V. Lailuck, and S. Supasitmongkol (2017). Pelletization of iron oxide based sorbents for hydrogen sulfide removal. In: Key Engineering Materials. Trans Tech Publication

Khalid A., Arshad, M., Anjum, M.Mahmood, T., Dawson L. (2011) The anaerobic digestion of solid organic waste. Waste management, 31(8), 1737-1744.

Krayzelova, L., Bartacek, J., Diaz I., Jenicek, P. (2015) Microaeration for hydrogen sulfide removal during anaerobic treatment: a review. Reviews in Environmental Science and Biotechnology, 14(4): 703-725.

Lissens, G., Vandevivere, P., De Baere L., Makaly Biey E., Verstrae W. (2001). Solid waste digesters: process performance and practice for municipal solid waste digestion. Water science and technology, 44(8): 91-102.

Massé, D.I., Rajagopal, R., and Singh, G. (2014) Technical and operational feasibility of psychrophilic anaerobic digestion biotechnology for processing ammonia-rich waste. Applied Energy,. 120: 49-55.

Micolucci, F., Gottardo, M., Bolzonella, D., Pavan, P. ( 2014) Automatic process control for stable bio-hythane production in two-phase thermophilic anaerobic digestion of food waste. International Journal of Hydrogen Energy. 39(31): 1756317572.

Moestedt, J., Nordell, E., Shakeri Y.S., Lundgeren J., Marti, A., Sundberg C., Ejlertsson J., Svensson, B.H., Björn A. (2016) Effects of trace element addition on process stability during anaerobic co-digestion of OFMSW and slaughterhouse waste. Waste management,. 47: 11-20.

Municipality of Tehran, Waste Management Organization. (2018) Report on field investigations for solid wastes composition and quantity within 22 urban districts of Tehran during 2008 and 2017. http://pasmand.tehran.ir (in Persian) accessed on 15 October 2019

Park, C.M., Novak,J.T. (2013) The effect of direct addition of iron (III) on anaerobic digestion efficiency and odor causing compounds. Water Science and Technology, 68(11): 23912396.

Silvestre, G., A. Bonmatí, and B. Fernández, (2015) Optimisation of sewage sludge anaerobic digestion through co-digestion with OFMSW: effect of collection system and particle size. Waste Management,. 43: 137-143. 
Syed, M., Sore.anu, G., Flatella, P., Beland, M. (2006) Removal of hydrogen sulfide from gas streams using biological processesA review. Canadian Biosystems Engineering, 48: 2.1-2.14

Tsachidou B. Scheuren M., Gennen J., Debbaut V., Toussaint B., Hissler C., George I., Delfosse, P. (2019) Biogas residues in substitution for chemical fertilizers: A comparative study on a grassland in the Walloon Region. Sci Total Environ. 2019 May 20;666:212-225. doi: 10.1016/j.scitotenv.

Vögeli, Y. (2014) Anaerobic digestion of biowaste in developing countries: Practical information and case studies. EawagSandec.

Wellinger, A., Murphy, J.D. and Baxter D. (2013) The biogas handbook: science, production and applications. Elsevier.
Wu, C., Huang, Q., Yu, M., Ren, Y., Wang, Q., Sakai, K. (2018) Effects of digestate recirculation on a two-stage anaerobic digestion system, particularly focusing on metabolite correlation analysis. Bioresource Technology. 251: 40-48.

Zulkefli, N.N., Masdar M.S., Wan Isahak, W.N., Md Jahim, J., Md Rejab S.A., Lye,C.C. (2019) Removal of hydrogen sulfide from a biogas mimic by using impregnated activated carbon adsorbent. PLOS ONE. 14(2): e0211713. DOI: $\underline{10.1371 / \text { journal.pone.0211713 }}$

(C) 2020. This article is an open access article distributed under the terms and conditions of the Creative Commons Attribution (CC BY) license (http://creativecommons.org/licenses/by/4.0/) 